\title{
EFIKASI CENDAWAN ENTOMOPATOGEN LECANICILLIUM LECANII TERHADAP BEMISIA TABACI (HEMIPTERA: ALEYRODIDAE) PADA KEDELAI
}

\author{
Yusmani Prayogo \\ Balai Penelitian Tanaman Aneka Kacang dan Umbi \\ Jln. Raya Kendalpayak, KM 08. PO BOX 66 Malang, 65101 \\ E-mail:manik_galek@yahoo.com
}

\begin{abstract}
Efficacy of entomopathogenic fungi Lecanicillium lecanii to Bemisia tabaci (Hemiptera: Aleyrodidae) on Soybean. Bemisia tabaci is one of the most important pests on soybean, because in addition to direct damage also as vectors of viruses and stimulated the growth of sooty mold. The efficacy of entomopathogenic fungi Lecanicillium lecanii to control B. tabaci carried out at Muneng field research station of Probolinggo in June until September 2012. Research using a split plot design, the main plot is two soybean varieties, namely Argomulyo and Wilis. Subplot is the time application of fungi $L$. lecanii with conidia densities of $10^{7}$ and $10^{9} / \mathrm{ml}$. The results showed that Argomulyo more preferred by $B$. tabaci compared Wilis variety. Nine times application of $L$. lecanii using $10^{7} / \mathrm{ml}$ conidia densities were applied every week the started on 14-70 days after planting (DAP) was able to suppress of $B$. tabaci in the field. However, planting Wilis varieties with nine times application of L. lecanii using conidia densities $10^{9} / \mathrm{ml}$ were recommended. Controlling of B. tabaci on Argomulyo variety use L. lecanii or lamda sihalotrin showed no significantly due to the result seed weight is lower than compare with Wilis untreated. Application of $L$. lecanii use with the highest conidia densities $\left(10^{9} / \mathrm{ml}\right)$, no negative effect to the survival on survival of various predators; i.e. Coccinella sp., Oxyopes sp. and Paederus sp. Therefore, L. lecanii most likely to be used as an effective biopesticide agent to control of $B$. tabaci and as substitute to chemical insecticides.
\end{abstract}

Key words: B. tabaci, L. lecanii, predator, soybean, time application

\begin{abstract}
ABSTRAK
Efikasi cendawan entomopatogen Lecanicillium lecanii terhadap Bemisia tabaci (Hemiptera: Aleyrodidae) pada kedelai. Bemisia tabaci merupakan salah satu hama penting pada kedelai. Selain merusak secara langsung, $B$. tabaci juga berperan sebagai vektor virus dan memicu tumbuhnya cendawan jelaga. Penelitian ini bertujuan untuk mempelajari efikasi cendawan entomopatogen Lecanicillium lecanii dalam mengendalikan B. tabaci. Penelitian dilakukan di kebun percobaan (KP) Muneng, Probolinggo pada bulan Juni sampai dengan September 2012. Penelitian menggunakan rancangan split plot. Petak utama adalah dua varietas kedelai, yaitu Argomulyo dan Wilis. Anak petak adalah periode waktu aplikasi cendawan L. lecanii yang menggunakan kerapatan konidia $10^{7}$ dan $10^{9} / \mathrm{ml}$. Hasil penelitian menunjukkan bahwa varietas Argomulyo lebih disukai $B$. tabaci dibandingkan varietas Wilis. Aplikasi cendawan L. lecanii menggunakan kerapatan konidia $10^{7} / \mathrm{ml}$ yang diaplikasikan setiap minggu sebanyak sembilan kali mulai umur 14-70 hari setelah tanam (HST) sudah mampu menekan populasi B. tabaci di lapangan. Namun untuk menekan kehilangan hasil, dianjurkan menanam varietas Wilis dengan aplikasi L. lecanii sembilan kali menggunakan kerapatan konidia $10^{9} / \mathrm{ml}$. Pengendalian B. tabaci pada varietas Argomulyo menggunakan L. lecanii maupun insektisida lamda sihalotrin tidak menunjukkan hasil yang signifikan karena berat biji yang dihasilkan lebih rendah dibandingkan dengan varietas Wilis tanpa pengendalian. Aplikasi cendawan L. lecanii menggunakan kerapatan konidia tertinggi (109/ml), tidak berpengaruh negatif terhadap kelangsungan hidup berbagai jenis serangga predator antara lain; Coccinella sp., Oxyopes sp. maupun Paederus sp. Oleh karena itu, cendawan entomopatogen $L$. lecanii berpeluang besar dapat digunakan sebagai biopestisida yang efektif untuk agens pengendalian $B$. tabaci dan sebagai alternatif pengganti insektisida kimia.
\end{abstract}

Kata kunci: B. tabaci, kedelai, L. lecanii, predator, waktu aplikasi

\section{PENDAHULUAN}

Bemisia tabaci (Genn.) (Hemiptera: Aleyrodidae) merupakan salah satu jenis hama kosmopolit sehingga dapat berkembang di berbagai tipe iklim, baik tropik maupun subtropik (Ren et al., 2001; Henneberry et al., 2002). Di Indonesia, B. tabaci menyerang berbagai jenis tanaman kacang-kacangan 
dengan populasi yang cukup tinggi selama tiga tahun terakhir. Bahkan populasi $B$. tabaci terus meningkat di berbagai tempat termasuk di beberapa kebun percobaan (KP) lingkup Balai Penelitian Tanaman Aneka Kacang dan Umbi (Balitkabi), terutama KP Muneng (Probolinggo). Bemicia tabaci menyebabkan kerugian secara langsung, yaitu serangga mengisap cairan tanaman pada permukaan daun (Gulluoglu et al., 2010a). Sedangkan kerugian secara tidak langsung karena $B$. tabaci berfungsi sebagai vektor dari berbagai macam virus (Perring, 2001). Kerugian tidak langsung lainnya adalah terbentuknya sekresi berupa embun madu (honeydew) yang memicu tumbuhnya cendawan jelaga (dark sooty mold) yang berwarna hitam di seluruh permukaan daun, sehingga mengurangi intensitas sinar matahari yang seharusnya digunakan untuk proses fotosintesis (Byrne \& Miller, 1990; Hendrix et al., 1992; Davidson et al., 1994; Isaacs et al., 1998; Hilje \& Morales, 2008).

B. tabaci berkembang biak optimal pada temperatur yang tinggi di atas $26^{\circ} \mathrm{C}$ dan kelembaban relatif $60 \%$. Perkembangan serangga di lapangan dimulai pada bulan Juni dan populasi optimal terjadi pada bulan Agustus (Hilje \& Morales, 2008; Lourencao et al., 2011). Seekor imago betina mampu memproduksi telur hingga mencapai 160 butir dalam setahun yang terdiri 11-12 generasi (Musa \& Ren, 2005). Telur diletakkan oleh imago pada permukaan daun bagian bawah, setelah kurang lebih tujuh hari telur akan menetas dan berkembang menjadi nimfa. Stadia nimfa $B$. tabaci terdiri tiga instar sebelum menjadi dewasa. Stadia nimfa maupun dewasa mempunyai peluang yang sama dalam menyebabkan kerusakan pada tanaman karena mengisap lapisan ploem yang mengandung berbagai jenis gula (Hendrix et al., 1992).

Teknologi pengendalian B. tabaci yang tersedia hingga saat ini hanya terbatas pada aplikasi insektisida kimia (Horowitz \& Inshaya,1996; Byrne et al., 2003; Ullah et al., 2006). Namun insektisida kimia, selain harganya yang relatif mahal juga mengakibatkan resistensi hama karena perkembangan $B$. tabaci yang sangat cepat hanya berlangsung 12 hari (Denholm et al., 1996; Horowitz \& Ishaya, 1996). Dengan demikian, aplikasi insektisida kimia menjadi kurang efektif dan keberadaan B. tabaci di lapangan tetap menjadi masalah yang sulit diatasi. Aplikasi insektisida kimia juga menimbulkan pencemaran lingkungan dan mematikan hampir seluruh serangga berguna, meliputi serangga penyerbuk, perombak (detrivor), maupun musuh alami baik parasitoid maupun predator.

Cendawan entomopatogen, Lecanicillium lecanii (Zimm.) Zare \& Gams yang sebelumnya juga disebut dengan L. muscarium dilaporkan efektif mengendalikan berbagai jenis hama terutama dari ordo Homoptera (Gindin et al., 1994). Efikasi L. lecanii tampak dari kelebihan cendawan tersebut karena mampu menggagalkan penetasan telur (ovicidal) (Prayogo, 2009), selain itu cendawan tersebut mampu menginfeksi seluruh stadia B. tabaci baik nimfa maupun imago (Ren et al., 2010). Dilaporkan lebih lanjut, bahwa kandungan toksin dari L. lecanii mampu menolak peletakan telur serangga (deterent oviposition) sehingga perkembangan populasi serangga di lapangan dapat tertekan (Wang et al., 2005). Penelitian ini bertujuan untuk mempelajari efikasi frekuensi aplikasi cendawan L. lecanii dalam mengendalikan B. tabaci pada kedelai.

\section{METODE PENELITIAN}

Tempat dan Waktu. Penelitian dilakukan di kebun percobaan (KP) Muneng, Probolinggo mulai bulan Juni sampai September 2012.

Rancangan Percobaan. Percobaan menggunakan rancangan petak terbagi, dengan tiga ulangan. Petak utama adalah varietas kedelai Argomulyo (V1; berbiji besar) dan Wilis (V2; berbiji kecil). Sedangkan anak petak adalah frekuensi aplikasi cendawan entomopatogen L. lecanii dengan kerapatan konidia dan aplikasi cendawan pada umur yang berbeda, sebagai berikut:

A1 = Kerapatan konidia 107/ml pada umur 14, 21, 28, 35, 42, 49, 56, 63, dan 70 HST.

$\mathrm{A} 2=$ Kerapatan konidia 107/ml pada umur 14, 21, 28, 42, 56, dan 70 HST.

A3 = Kerapatan konidia 10 $/ \mathrm{ml}$ pada umur 14, 21, 28, $35,42,49,56,63$, dan 70 HST.

A4 = Kerapatan konidia 10\% $/ \mathrm{ml}$ pada umur 14, 21, 28, 42, 56, dan 70 HST.

A5 = Aplikasi insektisida kimia lamda sihalotrin pada 14, 21, 28, 38, 45, 52, dan 59 HST.

A6 $=$ Kontrol (tanpa pengendalian).

Kedelai varietas Argomulyo dan Wilis ditanam pada plot yang berukuran $7 \times 5 \mathrm{~m}$, jarak tanam $40 \times 10$ $\mathrm{cm}$, setiap lubang diisi dua tanaman. Infestasi B. tabaci secara alamiah karena lokasi penelitian dan kondisi lingkungan sangat kondusif bagi perkembangan serangga ini. Berdasarkan perkembangan populasi $B$. tabaci di lokasi penelitian setiap tahun terjadi peledakan (outbreak) mulai tahun 2005.

Cendawan L. lecanii yang digunakan adalah koleksi dari laboratorium Entomologi (Balitkabi), yaitu isolat Ll-JTM11 yang memiliki virulensi tinggi hasil 
eksplorasi pada tahun 2009 (Prayogo, 2009). Cendawan tersebut dikulturkan pada media beras jagung, pada umur 21 hari biakan cendawan dicampur dengan air kemudian dikocok menggunakan shaker selama 30 menit untuk memisahkan konidia yang terbentuk. Suspensi konidia dihitung menggunakan haemocytometer hingga memperoleh kerapatan konidia $10^{9}$ dan $10^{7} / \mathrm{ml}$ sebagai perlakuan. Suspensi konidia cendawan L. lecanii sebelum diaplikasikan ditambah dengan larutan Tween 80 sebanyak $2 \mathrm{ml} / \mathrm{l}$ air. Aplikasi suspensi konidia $L$. lecanii dilakukan sesuai dengan waktu yang sudah ditentukan pada masing-masing perlakuan.

Sticky trap berukuran $30 \times 30 \mathrm{~cm}$ dipasang di atas permukaan tanaman di setiap plot perlakuan yang berlawanan arah angin dengan tujuan untuk mendeteksi populasi B. tabaci setelah diaplikasi cendawan L. lecanii. Pemasangan sticky trap dilakukan satu hari sebelum aplikasi dan satu hari setelah aplikasi suspensi L. lecanii. Pengambilan dan pemasangan sticky trap dilakukan setiap pukul 08:00 WIB.

Peubah yang diamati adalah; (1) populasi awal B. tabaci pada umur 13 HST kemudian dilanjutkan pada umur satu hari setelah aplikasi cendawan $L$. lecanii, (2) populasi hama utama kedelai selain B. tabaci, (3) populasi musuh alami, (4) intensitas kerusakan tanaman akibat B. tabaci dan (5) komponen hasil. Intensitas kerusakan dinilai dari tingkat serangan $B$. tabaci pada sepuluh tanaman contoh menggunakan skor, sebagai berikut:

0 = tanaman tidak terserang $B$. tabaci, daun tidak keriting dan permukaan daun tidak ditumbuhi cendawan jelaga.

1 = tanaman terserang B. tabaci, daun keriting dan permukaan daun ditumbuhi cendawan jelaga (0$25 \%)$.

2 = tanaman terserang $B$. tabaci, daun keriting dan permukaan daun ditumbuhi cendawan jelaga (26$50 \%)$.

3 = tanaman terserang B. tabaci, daun keriting dan permukaan daun ditumbuhi cendawan jelaga (51$75 \%$ ), polong dan biji berkembang tidak normal.

4 = tanaman terserang $B$. tabaci daun keriting dan permukaan daun ditumbuhi cendawan jelaga berkisar $>75 \%$, polong dan biji berkembang tidak normal.

Intensitas serangan B. tabaci selanjutnya dihitung menggunakan rumus sebagai berikut:

$$
\mathrm{I}=\sum \frac{(n i \times v i)}{Z N} \times 100 \%
$$

Keterangan :

I = Intensitas serangan (\%)

$\mathrm{ni}=$ banyaknya daun yang menunjukkan skor ke-i

$\mathrm{vi}=$ skor daun ke-i $(\mathrm{i}=0-4)$

$\mathrm{Z}=$ skor tertinggi (4)

$\mathrm{N}$ = banyaknya daun yang diamati

\section{HASIL DAN PEMBAHASAN}

\section{Pengaruh Aplikasi Cendawan L. lecanii terhadap}

Populasi B. tabaci. Populasi B. tabaci diamati dengan cara memasang perangkap kuning (sticky trap) di seluruh permukaan tanaman pada setiap plot-plot perlakuan. Populasi B. tabaci yang tertangkap pada sticky trap satu hari sebelum aplikasi cendawan $L$. lecanii, yaitu pada umur 13 hari setelah tanam (HST) berkisar 13-28 ekor (Tabel 1). Sementara itu, pengamatan visual dengan menghitung jumlah populasi pada tiap tanaman ditemukan imago $B$. tabaci sebanyak 12 ekor tiap rumpun. Berdasarkan nilai ambang kendali terhadap semua jenis serangga hama yang berfungsi sebagai vektor virus ditentukan satu ekor tiap tanaman, oleh karena itu infestasi buatan B. tabaci tidak perlu dilakukan di lahan percobaan.

Populasi B. tabaci ditemukan lebih banyak pada varietas kedelai yang berbiji besar (Argomulyo) dibandingkan dengan kedelai berbiji kecil (Wilis). Satu hari setelah aplikasi L. lecanii, tampak terjadi peningkatan populasi $B$. tabaci lebih banyak terutama pada varietas Argomulyo. Pada varietas Wilis meskipun terjadi peningkatan populasi, namun peningkatannya tidak sebesar pada varietas Argomulyo. Aplikasi cendawan $L$. lecanii sebanyak sembilan kali yang dilakukan setiap minggu $(14,21,28,35,42,48,55,62$ dan 70 HST) mampu menekan perkembangan populasi B. tabaci jika dibandingkan dengan aplikasi hanya lima kali $(14,28,42,55$ dan 70 HST), baik pada varietas Argomulyo maupun varietas Wilis. Meskipun populasi B. tabaci lebih tinggi pada perlakuan yang diaplikasi dengan L. lecanii hanya lima kali, namun populasi tersebut tidak berbeda nyata dengan perlakuan aplikasi L. lecanii sembilan kali. Efikasi L. lecanii dalam mengendalikan $B$. tabaci setara dengan keefektifan insektisida kimia (lamda sihalotrin) karena secara statistik tidak berbeda nyata, baik pada varietas Argomulyo maupun Wilis.

Populasi B. tabaci semakin bertambah banyak dengan bertambahnya umur tanaman. Pengamatan pada umur $22 \mathrm{HST}$, populasi B. tabaci semakin bertambah banyak bahkan hingga di atas 150 ekor yang tertangkap pada perlakuan kontrol (tanpa aplikasi cendawan L. lecanii). Penanaman kedelai berbiji kecil (Wilis) yang 
Tabel 1. Populasi B. tabaci yang tertangkap pada sticky trap setelah diaplikasi dengan cendawan L. lecanii

\begin{tabular}{ccccccccccc}
\hline Varietas & \multicolumn{7}{c}{ Populasi B. tabaci yang tertangkap sticky trap sehari sesudah aplikasi cendawan L. lecanii (ekor) } \\
\cline { 2 - 10 } Aplikasi & $13 \mathrm{HST}$ & $15 \mathrm{HST}$ & $22 \mathrm{HST}$ & $29 \mathrm{HST}$ & $36 \mathrm{HST}$ & $43 \mathrm{HST}$ & $49 \mathrm{HST}$ & $56 \mathrm{HST}$ & $63 \mathrm{HST}$ & $71 \mathrm{HST}$ \\
\hline V1A1 & $24 \mathrm{a}$ & $30 \mathrm{~b}$ & $121 \mathrm{bc}$ & $59 \mathrm{ab}$ & $263 \mathrm{a}$ & $267 \mathrm{a}$ & $596 \mathrm{~b}$ & $3376 \mathrm{ab}$ & $3397 \mathrm{a}$ & $333 \mathrm{bc}$ \\
V1A2 & $23 \mathrm{a}$ & $35 \mathrm{~b}$ & $144 \mathrm{bc}$ & $59 \mathrm{ab}$ & $293 \mathrm{a}$ & $290 \mathrm{a}$ & $646 \mathrm{~b}$ & $3396 \mathrm{ab}$ & $3210 \mathrm{a}$ & $316 \mathrm{~b}$ \\
V1A3 & $20 \mathrm{a}$ & $21 \mathrm{~b}$ & $110 \mathrm{c}$ & $57 \mathrm{abc}$ & $246 \mathrm{a}$ & $211 \mathrm{a}$ & $550 \mathrm{~b}$ & $3152 \mathrm{ab}$ & $3029 \mathrm{a}$ & $245 \mathrm{bcd}$ \\
V1A4 & $17 \mathrm{a}$ & $41 \mathrm{~b}$ & $120 \mathrm{bc}$ & $59 \mathrm{ab}$ & $255 \mathrm{a}$ & $238 \mathrm{a}$ & $570 \mathrm{~b}$ & $3155 \mathrm{ab}$ & $3155 \mathrm{a}$ & $336 \mathrm{~b}$ \\
V1A5 & $18 \mathrm{a}$ & $22 \mathrm{~b}$ & $110 \mathrm{c}$ & $49 \mathrm{abc}$ & $218 \mathrm{a}$ & $172 \mathrm{a}$ & $525 \mathrm{~b}$ & $2532 \mathrm{~b}$ & $2546 \mathrm{a}$ & $245 \mathrm{bcd}$ \\
V1A6 & $28 \mathrm{a}$ & $80 \mathrm{a}$ & $158 \mathrm{a}$ & $63 \mathrm{a}$ & $304 \mathrm{a}$ & $296 \mathrm{a}$ & $966 \mathrm{a}$ & $3775 \mathrm{a}$ & $3397 \mathrm{a}$ & $512 \mathrm{a}$ \\
V2A1 & $16 \mathrm{a}$ & $19 \mathrm{~b}$ & $109 \mathrm{c}$ & $57 \mathrm{abc}$ & $220 \mathrm{a}$ & $258 \mathrm{a}$ & $475 \mathrm{~b}$ & $2532 \mathrm{ab}$ & $2687 \mathrm{a}$ & $252 \mathrm{bcd}$ \\
V2A2 & $15 \mathrm{a}$ & $28 \mathrm{~b}$ & $110 \mathrm{c}$ & $49 \mathrm{abc}$ & $241 \mathrm{a}$ & $281 \mathrm{a}$ & $541 \mathrm{~b}$ & $2934 \mathrm{~b}$ & $2845 \mathrm{a}$ & $102 \mathrm{~cd}$ \\
V2A3 & $13 \mathrm{a}$ & $17 \mathrm{~b}$ & $75 \mathrm{~d}$ & $41 \mathrm{c}$ & $223 \mathrm{a}$ & $167 \mathrm{a}$ & $416 \mathrm{~b}$ & $2853 \mathrm{~b}$ & $2649 \mathrm{a}$ & $144 \mathrm{~d}$ \\
V2A4 & $15 \mathrm{a}$ & $17 \mathrm{~b}$ & $109 \mathrm{c}$ & $45 \mathrm{bc}$ & $233 \mathrm{a}$ & $208 \mathrm{a}$ & $477 \mathrm{~b}$ & $2459 \mathrm{~b}$ & $2678 \mathrm{a}$ & $225 \mathrm{bcd}$ \\
V2A5 & $15 \mathrm{a}$ & $17 \mathrm{~b}$ & $105 \mathrm{c}$ & $46 \mathrm{abc}$ & $197 \mathrm{a}$ & $135 \mathrm{a}$ & $319 \mathrm{~b}$ & $2459 \mathrm{~b}$ & $2152 \mathrm{a}$ & $251 \mathrm{bcd}$ \\
V2A6 & $28 \mathrm{a}$ & $53 \mathrm{ab}$ & $152 \mathrm{a}$ & $59 \mathrm{ab}$ & $286 \mathrm{a}$ & $284 \mathrm{a}$ & $623 \mathrm{ab}$ & $3412 \mathrm{ab}$ & $3228 \mathrm{a}$ & $328 \mathrm{bc}$ \\
\hline KK $(\%)$ & 35,34 & 47,02 & 21,39 & 17,80 & 22,08 & 30,03 & 11,45 & 16,16 & 22,29 & 37,54 \\
DMRT $(0,05)$ & 18 & 38 & 25 & 17 & 116 & 181 & 346 & 1101 & 1125 & 136 \\
\hline
\end{tabular}

Keterangan: V1 = varietas Agromulyo; V2 = varietas Wilis

diaplikasi dengan cendawan $L$. lecanii tampak lebih efektif dalam menekan populasi B. tabaci dibandingkan dengan kedelai berbiji besar (Argomulyo). Aplikasi L. lecanii sebanyak sembilan kali lebih efektif terutama yang menggunakan kerapatan konidia $10^{\%} / \mathrm{ml}$ apabila dibandingkan dengan kerapatan konidia $10^{7} / \mathrm{ml}$. Meskipun demikian, kerapatan konidia $10^{9} / \mathrm{ml}$ tidak berbeda nyata dengan kerapatan konidia $10^{7} / \mathrm{ml}$ apabila yang ditanam adalah varietas Argomulyo.

Aplikasi suspensi konidia cendawan $L$. lecanii pada umur 28 HST menyebabkan penurunan populasi B. tabaci. Hal ini dapat dibuktikan dari pengamatan pada umur 29 HST populasi lebih rendah apabila dibandingkan dengan populasi B. tabaci pada umur 22 HST. Pada pengamatan tersebut populasi B. tabaci pada varietas Wilis di lapangan tampak lebih rendah dibandingkan dengan varietas Argomulyo. Aplikasi cendawan $L$. lecanii sebanyak sembilan kali menggunakan kerapatan konidia $10^{9} / \mathrm{ml}$ lebih efektif dalam menekan populasi $B$. tabaci dibandingkan dengan perlakuan lainnya, bahkan lebih efekif apabila dibandingkan dengan efikasi dari insektisida lamda sihalotrin.

Populasi B. tabaci meningkat lebih tinggi pada tanaman yang berumur 36, 43 dan 49 HST, namun diantara perlakuan yang diuji tidak berbeda nyata kecuali tanpa perlakuan pada umur 49 HST. Efikasi insektisida kimia pada ketiga pengamatan tersebut lebih tinggi dalam menekan populasi $B$. tabaco, baik pada varietas Argomulyo maupun Wilis, namun efikasi insektisida kimia tidak berbeda nyata dengan aplikasi dengan $L$. lecanii. Populasi B. tabaci pada varietas Wilis tetap konsisten lebih rendah dibandingkan dengan varietas Argomulyo. Peningkatan populasi $B$. tabaci cukup tinggi yaitu hingga di atas 3000 ekor pada tanaman yang berumur 56 dan 63 HST. Populasi B. tabaci tertinggi terjadi pada perlakuan varietas Argomulyo terutama yang hanya mendapat aplikasi L. lecanii lima kali. Perbedaan kerapatan konidia L. lecanii antara $10^{7} / \mathrm{ml}$ dan $10^{9} / \mathrm{ml}$ menyebabkan perbedaan peningkatan keefektifan cendawan dalam mengendalikan B. tabaci. Namun efikasi dari kedua jenis kerapatan konidia $L$. lecanii tersebut secara statistik tidak berbeda nyata.

Perbedaan kelimpahan populasi $B$. tabaci pada varietas Argomulyo dibandingkan dengan varietas Wilis diduga karena berhubungan dengan kerapatan trikom yang dimiliki oleh varietas Argomulyo. Trikom yang rapat akan lebih aman untuk menyembunyikan telur-telur serangga yang baru diletakkan oleh imago betina (Mansaray \& Sundufu 2009). Fenomena ini berbeda dengan yang dilaporkan oleh Lam \& Pedigo (2001) serta Junior et al. (2007), trikom pada tanaman kapas yang 
lebih rapat tidak disukai oleh $B$. tabaci untuk meletakkan telurnya. Hal ini disebabkan karena semakin banyak trikom, semakin banyak pula kandungan kelenjar senyawa gosipol yang dikeluarkan oleh tanaman tersebut. Perlu diketahui bahwa gosipol yang dihasilkan oleh kelenjar trikom kapas merupakan senyawa sekunder yang dihasilkan oleh tanaman kapas sebagai racun bagi serangga herbivor (Butter et al., 1990; Wilson et al., 1993).

Populasi B. tabaci pada umur 70 HST, tampak terjadi penurunan yang sangat signifikan karena populasi hanya berkisar 100-300 ekor. Populasi B. tabaci tertinggi terjadi pada penggunaan varietas Argomulyo terutama yang hanya mendapat aplikasi $L$. lecanii sebanyak lima kali. Sedangkan aplikasi $L$. lecanii sebanyak sembilan kali tampak lebih efektif dalam menekan perkembangan populasi B. tabaci. Aplikasi suspensi cendawan L. lecanii tampak cukup efektif dalam mengendalikan B. tabaci karena setara dengan efikasi insektisida lamda sihalotrin. Efikasi L. lecanii dapat dibuktikan dengan adanya kolonisasi miselium cendawan pada tubuh imago B. tabaci yang mati pada permukaan daun kedelai (Gambar 1). Kolonisasi miselium cendawan L. lecanii berwarna putih tampak pada hari keempat setelah aplikasi.

Hasil penelitian ini mengindikasikan bahwa penanaman varietas kedelai yang berbiji besar dan memiliki trikom lebih rapat akan meningkatkan populasi B. tabaci sehingga kerusakan tanaman juga akan semakin meningkat. Kerapatan konidia cendawan L. lecanii $10^{7} / \mathrm{ml}$ yang diaplikasikan setiap minggu sebanyak sembilan kali mulai umur 14 HST sudah cukup efektif dalam menekan populasi B. tabaci. Rendahnya populasi $B$. tabaci pada tanaman kedelai yang berumur lebih tua, diduga daun yang berumur tua sudah tidak menarik sebagai tempat untuk peletakan telur maupun sebagai sumber makanan. B. tabaci memilih daun untuk diisap cairannya sebagai sumber nutrisi bagi perkembangbiakan serangga, sementara itu daun yang berumur tua sudah terbatas kandungan airnya dan struktur fisik tanaman tidak disukai oleh imago. Menurut McAuslane (1996) dan Mansaray \& Sundufu (2009), tanaman kedelai yang berumur lebih tua tidak disukai oleh B. tabaci sebagai temat peletakan telur.

Tinggi Tanaman. Gejala serangan B. tabaci yang mudah dilihat pada tanaman kedelai adalah terjadinya pemendekan tanaman (stunting). Hasil penelitian menunjukkan bahwa tinggi tanaman tidak berbeda nyata antara perlakuan aplikasi cendawan entomopatogen $L$. lecanii dengan kontrol (tanpa pengendalian). Hal ini disebabkan di lahan percobaan terjadi ledakan $B$. tabaci yang cukup berat sehingga tanaman sebelum memperoleh aplikasi $L$. lecanii juga sudah terserang B. tabaci. Efikasi aplikasi L. lecanii yang signifikan tampak pada daun kedelai yang tidak ditumbuhi oleh cendawan jelaga yang berwarna hitam dan tidak mengalami keriting. Sementara itu, pada tanaman kontrol (tanpa pengendalian) menunjukkan gejala adanya embun jelaga dan daun mengeriting. Salah satu indikasi serangan berat $B$. tabaci selain kerdil yaitu adanya embun jelaga dan daun mengeriting. Tinggi tanaman kedelai yang mendapat perlakuan aplikasi cendawan $L$. lecanii tampak lebih tinggi berkisar 2-3 cm dibandingkan dengan kontrol (Gambar 2).

Menurut Botha et al. (2007) dampak serangan B. tabaci mampu mengakibatkan tanaman menjadi kerdil (stunting), hal ini disebabkan pertumbuhan

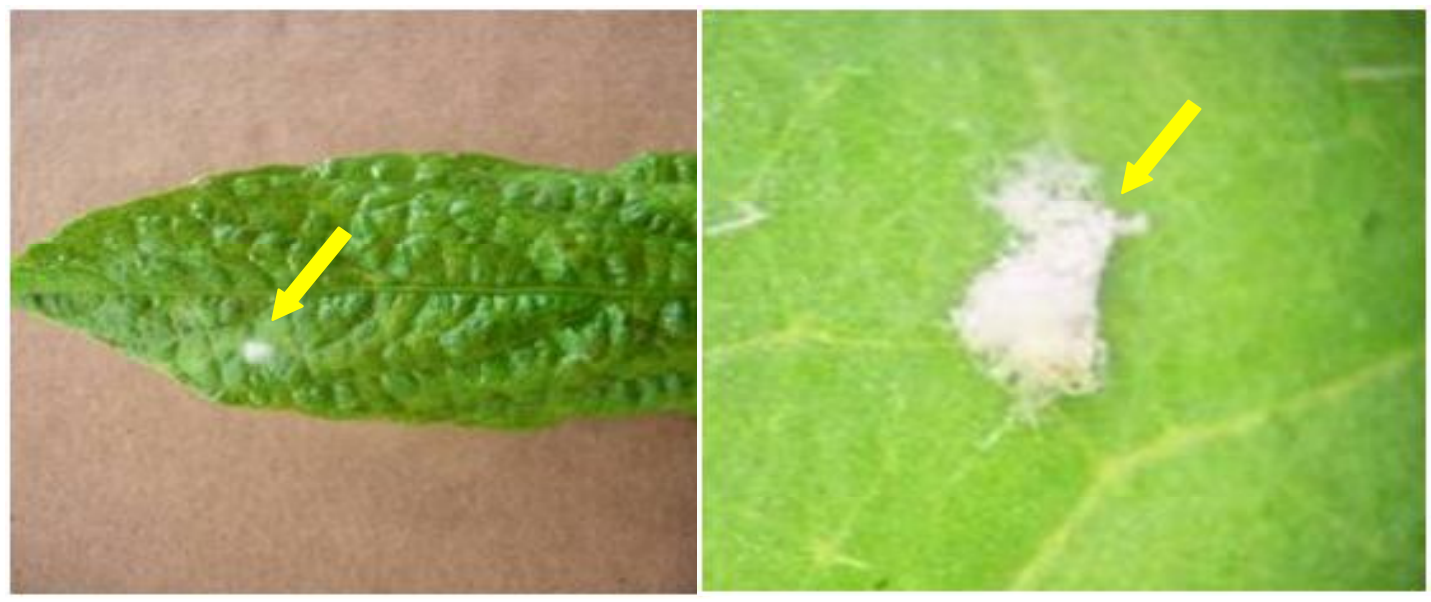

Gambar 1. B. tabaci mati terinfeksi dan terkolonisasi miselium cendawan L. lecanii setelah empat hari aplikasi. 


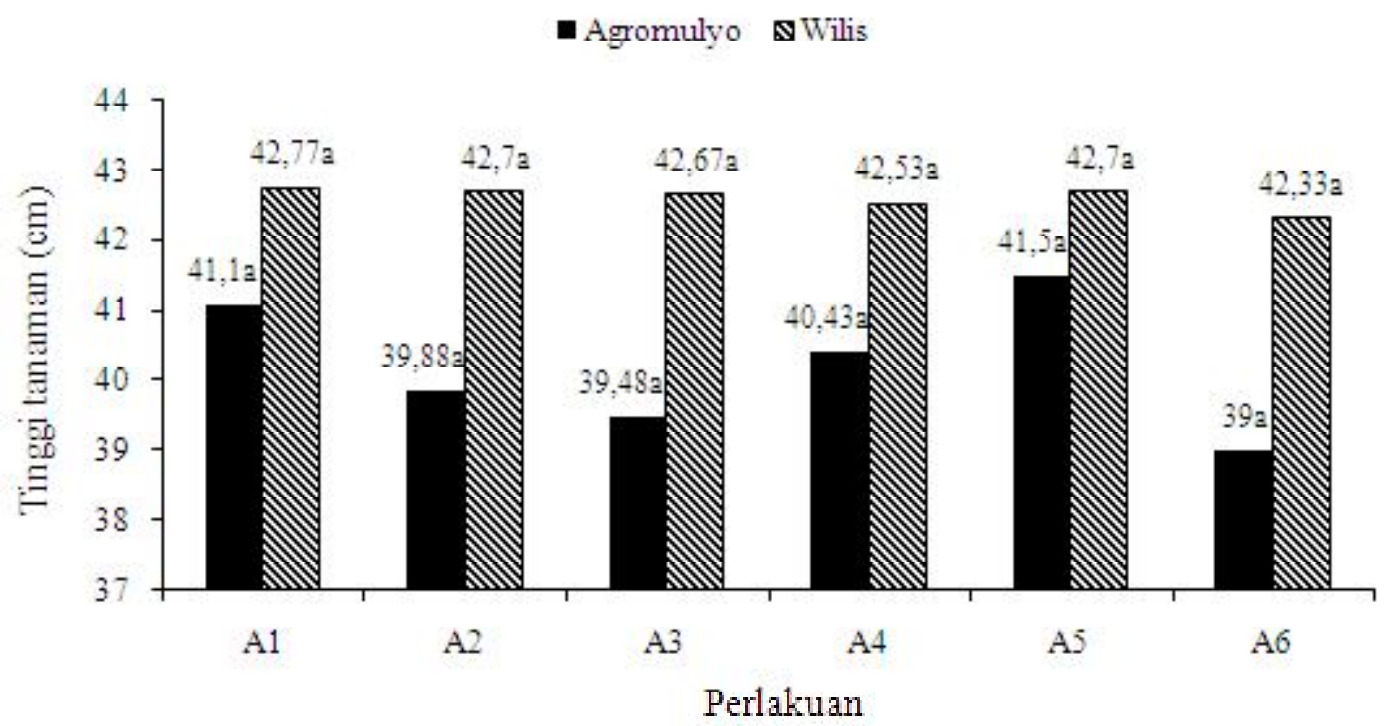

Gambar 2. Tinggi tanaman varietas Argomulyo dan Wilis setelah diaplikasi menggunakan cendawan L. lecanii

tanaman terhambat dalam proses fotosintesis. Keadaan ini terjadi karena seluruh permukaan daun tertutup oleh cendawan jelaga (dark sooty mold) yang tumbuh akibat embun madu yang disekresikan oleh $B$. tabaci. Selain itu, gejala serangan $B$. tabaci dapat menyebabkan daundaun menjadi keriting akibat infeksi virus yang ditularkan serangga tersebut (Perez et al., 2009; Islam \& Shunxiang 2009; Gulluoglu et al., 2010b). Menurut Sidhu et al. (2009) serangga $B$. tabaci merupakan vektor berbagai macam virus, khususnya cowpea mild mottle virus (CMMV) dengan gejala belang samar, daun mengeriput dan mengecil serta tanaman menjadi kerdil apabila intensitas serangan cukup parah.

Intensitas Serangan B. tabaci. Intensitas serangan B. tabaci dinilai dari kerusakan tanaman yang ditandai dengan gejala keriting pada daun dan tumbuhnya cendawan jelaga yang berwarna hitam menutup seluruh permukaan daun bagian atas. Hasil penelitian menunjukkan bahwa intensitas kerusakan tanaman akibat B. tabaci pada umur 42 HST yang diaplikasi cendawan $L$. lecanii sangat rendah karena hanya sekitar $10 \%$ terutama pada varietas Wilis. Sementara itu, intensitas serangan B. tabaci pada varietas Argomulyo lebih tinggi mencapai $20 \%$, bahkan pada perlakuan kontrol (tanpa pengendalian) hingga mencapai $27 \%$ (Tabel 2).

Intensitas serangan B. tabaci pada umur 57 HST terjadi peningkatan mencapai dua kali lipat jika dibandingkan dengan intensitas pada umur 42 HST. Perlakuan aplikasi cendawan $L$. lecanii sebanyak 9 kali menggunakan kerapatan konidia $10^{7} / \mathrm{ml}$ menunjukkan tingkat serangan $B$. tabaci lebih rendah jika dibandingkan dengan aplikasi menggunakan kerapatan konidia $10 \% \mathrm{ml}$ pada varietas Wilis maupun Argomulyo. Fenomena ini mengindikasikan bahwa aplikasi cendawan L. lecanii sebanyak 9 kali menggunakan kerapatan konidia $10^{7} / \mathrm{ml}$ sudah cukup untuk mengendalikan $B$. tabaci pada lahan yang terjadi ledakan (outbreak).

Intensitas serangan $B$. tabaci pada varietas Argomulyo cenderung lebih tinggi dibandingkan dengan varietas Wilis, baik pada tanaman umur 42 maupun 57 HST. Meskipun demikian, pada varietas Argomulyo yang memperoleh aplikasi cendawan $L$. lecanii secara visual tidak banyak ditemukan cendawan jelaga yang tumbuh dan menutup permukaan daun (Gambar 3a \& 3b). Sedangkan pada tanaman border tanpa pengendalian tampak ditumbuhi cendawan jelaga yang menutup seluruh permukaan daun kelihatan sangat hitam (Gambar 3c). Cendawan L. lecanii menghasilkan berbagai senyawa toksin yang berfungsi sebagai penghalau/penolak proses oviposisi atau proses peletakan telur serangga hama. Senyawa toksin yang dihasilkan oleh cendawan $L$. lecanii bersifat menolak (deterent) sehingga tidak disukai oleh imago B. tabaci untuk meletakkan telurnya pada organ tanaman (Wang et al. 2007). Beberapa jenis toksin yang dihasilkan oleh cendawan L. lecanii yaitu beauvericin, dipicolinic acid, hydroxycarboxilic acid, dan cyclosporin yang dilaporkan sangat toksik terhadap serangga (Charnley, 2003a \& 2003b; Murakoshi et al., 2005).

Jumlah Polong Isi Tiap Tanaman. Jumlah polong isi yang diperoleh pada varietas Wilis jauh lebih banyak 
Tabel 2. Intensitas serangan B. tabaci pada tanaman kedelai umur 42 dan 57 HST

\begin{tabular}{ccc}
\hline \multirow{2}{*}{ Perlakuan } & \multicolumn{2}{c}{ Persentase serangan B. tabaci pada hari ke.. $\mathrm{n}$ (HST) } \\
\cline { 2 - 3 } & 42 & 57 \\
\hline V1 A1 & $19,59 \mathrm{bc}$ & $27,03 \mathrm{bcde}$ \\
V1 A2 & $21,64 \mathrm{~b}$ & $30,84 \mathrm{ab}$ \\
V1 A3 & $14,87 \mathrm{bcd}$ & $25,52 \mathrm{bcde}$ \\
V1 A4 & $19,13 \mathrm{bc}$ & $28,56 \mathrm{bcd}$ \\
V1 A5 & $8,93 \mathrm{~d}$ & $24,40 \mathrm{cde}$ \\
V1 A6 & $27,48 \mathrm{a}$ & $31,57 \mathrm{a}$ \\
V2 A1 & $10,63 \mathrm{~cd}$ & $23,58 \mathrm{cde}$ \\
V2 A2 & $10,81 \mathrm{~cd}$ & $23,99 \mathrm{cde}$ \\
V2 A3 & $8,72 \mathrm{~d}$ & $22,90 \mathrm{de}$ \\
V2 A4 & $10,58 \mathrm{~cd}$ & $23,11 \mathrm{cde}$ \\
V2 A5 & $8,10 \mathrm{~d}$ & $21,99 \mathrm{e}$ \\
V2 A6 & $25,63 \mathrm{a}$ & $28,95 \mathrm{abc}$ \\
\hline KK $(\%)$ & 29,11 & 15,31 \\
DMT $(0,05)$ & 6,14 & 2,91 \\
\hline
\end{tabular}

Keterangan: V1 = varietas Agromulyo; V2 = varietas Wilis
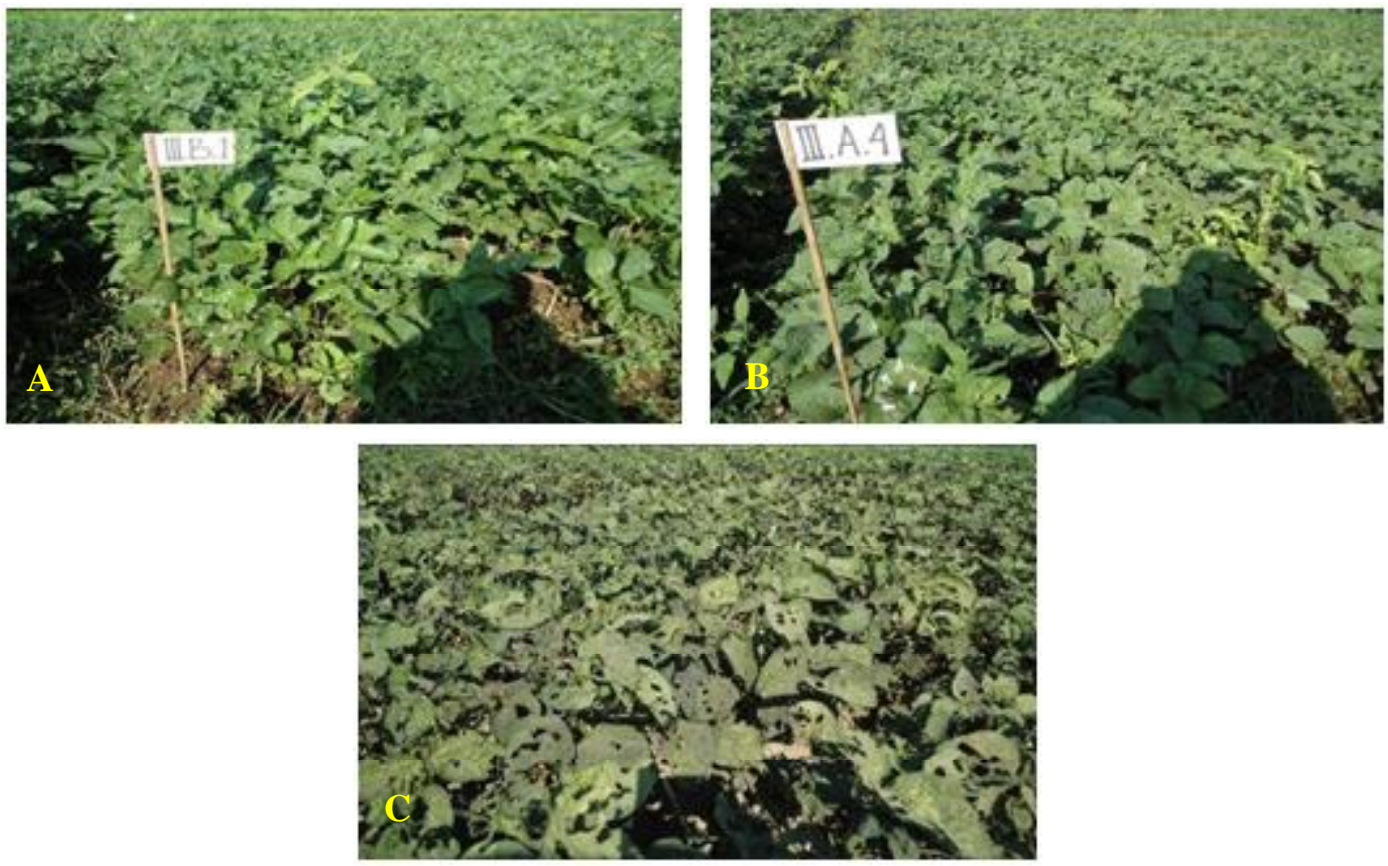

Gambar 3. Keragaan kedelai varietas Wilis (A) dan Argomulyo (B) yang diaplikasi cendawan L. lecanii serta varietas Argomulyo yang tertutup cendawan jelaga akibat sekresi dari B. tabaci (C).

jika dibandingkan dengan varietas Argomulyo. Jumlah polong isi terbanyak yaitu hingga mencapai 57,13 buah tiap batang pada varietas Wilis yang memperoleh aplikasi L. lecanii sebanyak 9 kali menggunakan kerapatan konidia $10 \% / \mathrm{ml}$ (Gambar 4). Namun perlakuan tersebut tidak berbeda nyata dengan perlakuan aplikasi $L$. lecanii sebanyak lima kali menggunakan kerapatan konidia $10^{\%}$ / ml $(56,07)$, aplikasi sembilan kali menggunakan 


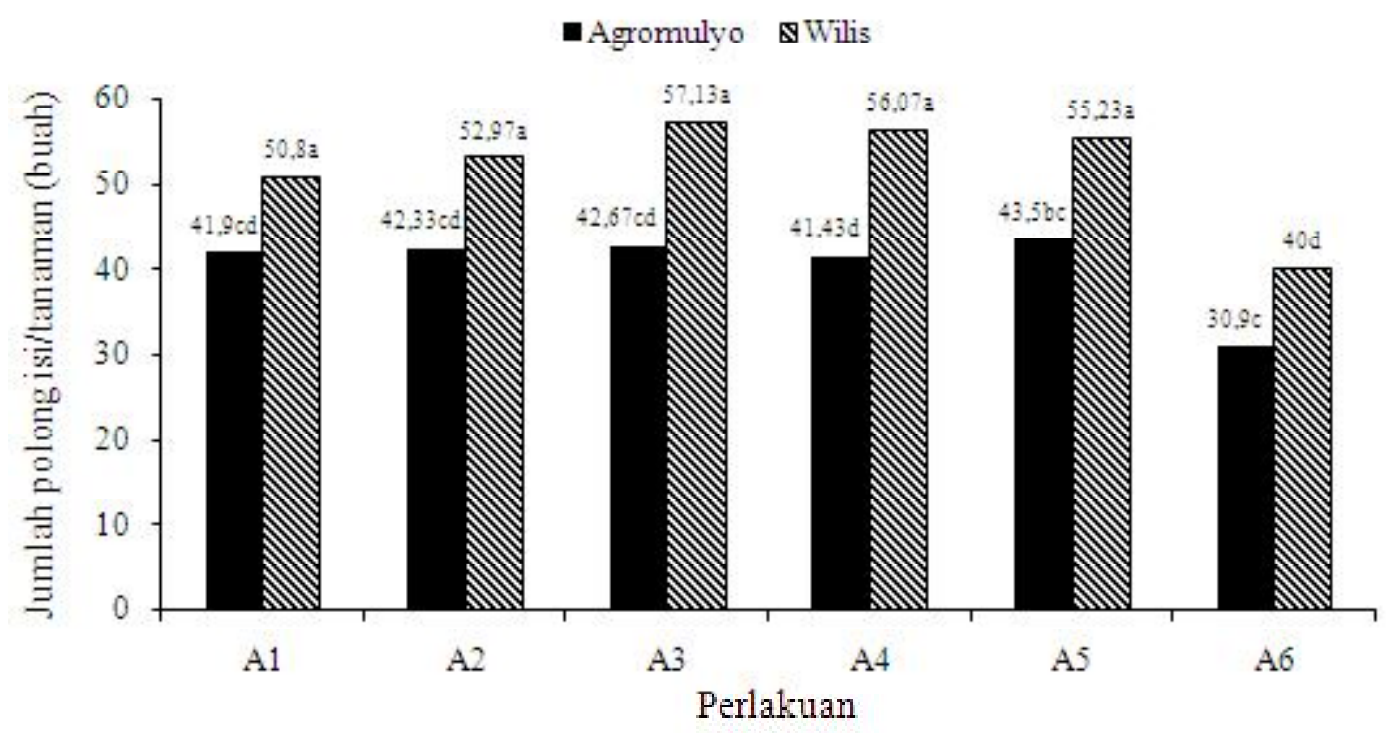

Gambar 4. Jumlah polong isi varietas Wilis dan Argomulyo terserang B. tabaci yang diaplikasi menggunakan cendawan L. lecanii.

kerapatan konidia $10^{7} / \mathrm{ml}(50,80)$, dan aplikasi lima kali kerapatan konidia $10^{7} / \mathrm{ml}(52,97)$ maupun aplikasi insektisida lamda sihalotrin $(55,23)$. Sementara itu, jumlah polong isi pada varietas Argomulyo berkisar 41$42 \mathrm{buah} / \mathrm{batang}$ dan tidak berbeda nyata dengan varietas Wilis tanpa pengendalian (40 buah/batang). Hasil penelitian ini mengindikasikan bahwa untuk mempertahankan jumlah polong isi maka dianjurkan menggunakan varietas Wilis akan lebih baik dibandingkan varietas Argomulyo yang berbiji besar karena varietas Argomulyo sangat rentan dan kondusif untuk perkembangan $B$. tabaci. Menurut Lambert et al. (1997) dan Gulluoglu et al. (2010a) varietas yang rentan terhadap B. tabaci maka jumlah polong isi yang terbentuk sangat terbatas, selain itu ukuran polong juga tidak normal karena pada waktu pengisian polong, tanaman tidak dapat melakukan proses fotosintensis dengan sempurna.

Jumlah Polong Hampa. Jumlah polong hampa terbanyak terjadi pada perlakuan kontrol (tanpa pengendalian), yaitu 4,3 buah tiap batang terjadi pada varietas Argomulyo (Gambar 5). Penggunaan varietas Argomulyo menyebabkan jumlah polong hampa yang terbentuk lebih banyak jika dibandingkan dengan varietas Wilis. Jumlah polong hampa yang terjadi pada varietas Wilis lebih rendah terutama dengan perlakuan aplikasi L. lecanii sebanyak sembilan kali dengan kerapatan konidia $10^{9} / \mathrm{ml}$ meskipun perlakuan tersebut tidak berbeda nyata.

Hasil penelitian ini mengindikasikan bahwa efikasi cendawan L. lecanii dengan aplikasi sebanyak 9 kali menggunakan kerapatan konidia $10^{9} / \mathrm{ml}$ setara dengan efikasi insektisida kimia dalam menekan jumlah polong hampa yang terbentuk. Aplikasi L. lecanii sembilan kali mengakibatkan populasi dan intensitas serangan B. tabaci juga lebih rendah, sehingga tanaman dapat melakukan proses fisiologi secara optimal. Menurut Gulluoglu et al. (2010b), tingkat kerugian hasil yang disebabkan oleh $B$. tabaci sangat bervariasi mulai rendah hingga berat. Serangan berat dapat menurunkan produksi kedelai, baik kualitas maupun kuantitas karena banyak biji yang hampa akibat tidak terisi secara optimal (Arioglu et al., 1989a \& 1989b).

Berat Biji Tiap Tanaman. Berat biji tiap tanaman tertinggi, yaitu mencapai 7,56 g terjadi pada perlakuan aplikasi cendawan $L$. lecanii sebanyak sembilan kali menggunakan kerapatan konidia $10^{9} / \mathrm{ml}$ pada varietas Wilis (Gambar 6). Sementara itu, rata-rata berat biji pada varietas Argomulyo lebih rendah dibandingkan varietas Wilis, kecuali pada perlakuan aplikasi sembilan kali menggunakan kerapatan konidia $10^{9} / \mathrm{ml}$ dan aplikasi insektisida kimia. Berat biji tiap tanaman terendah terjadi pada perlakuan kontrol, yaitu rata-rata hanya 6,16 - 6,47 yang terjadi pada kedua varietas yang diuji baik Argomulyo maupun Wilis. Hasil penelitian ini menunjukkan bahwa penggunaan varietas Wilis yang diaplikasi menggunakan cendawan $L$. lecanii sebanyak sembilan kali dengan kerapatan konidia $10^{9} / \mathrm{ml}$ cukup efektif dan sebanding dengan efikasi insektisida kimia yang berbahan aktif lamda sihalotrin.

Hasil penelitian ini mengindikasikan bahwa cendawan $L$. lecanii cukup efekif dalam mengendalikan 


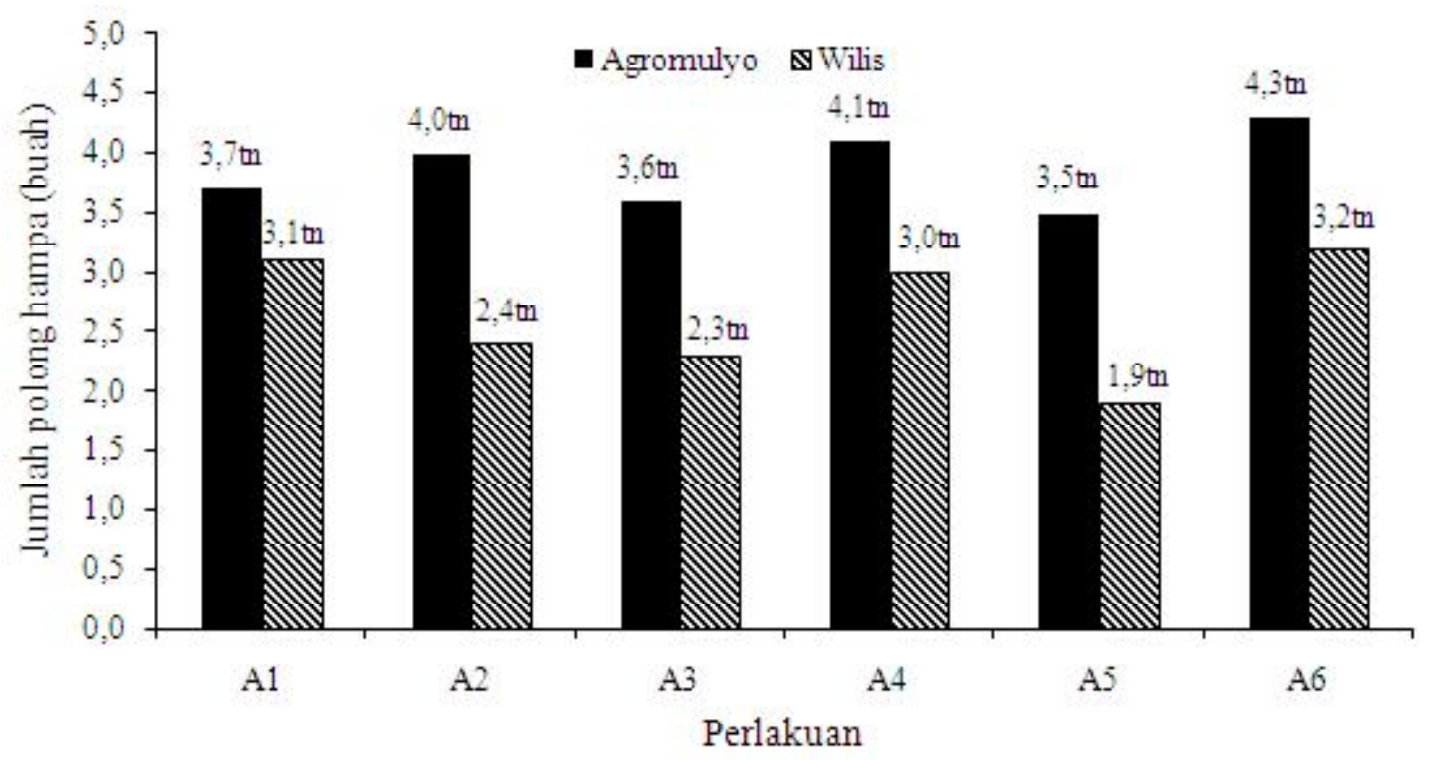

Gambar 5. Jumlah polong hampa yang terbentuk pada varietas Argomulyo dan Wilis setelah diaplikasi dengan cendawan L. lecanii

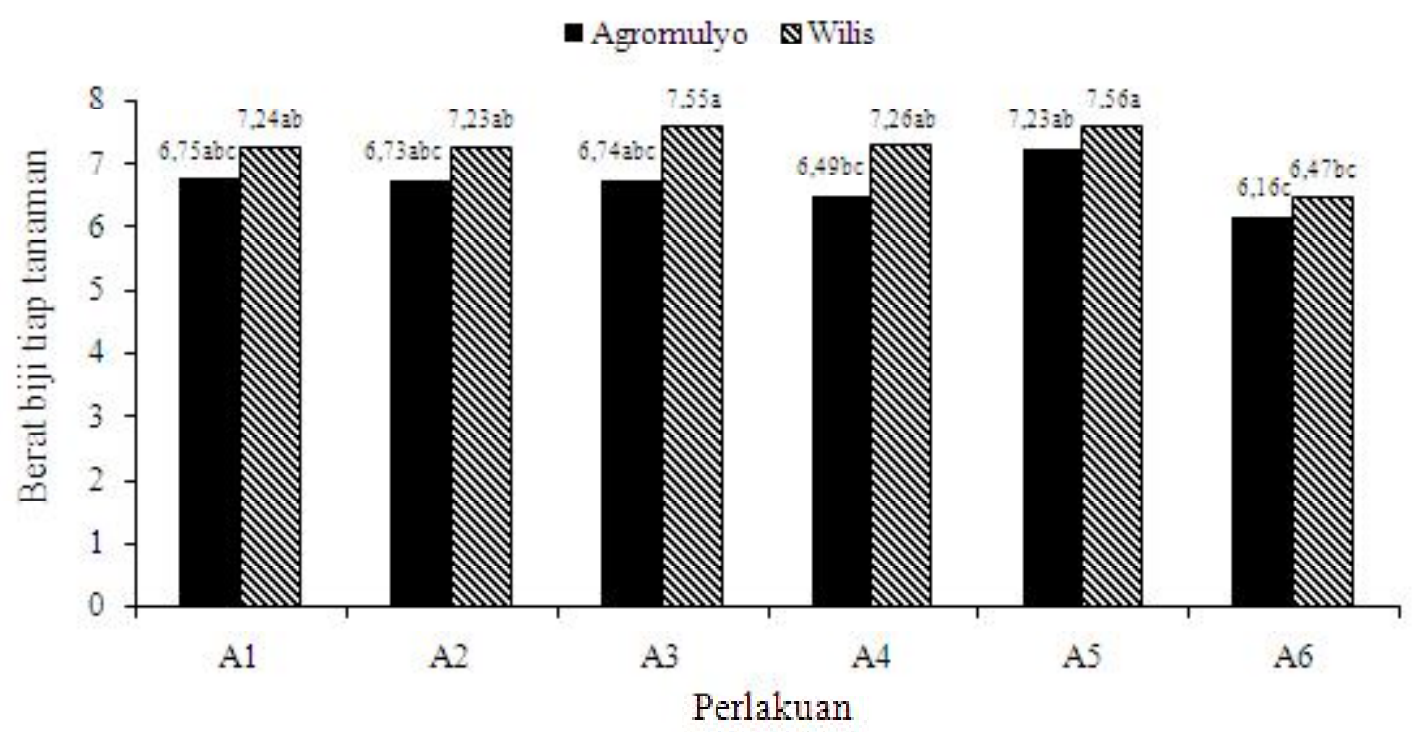

Gambar 6. Berat kering biji tiap tanaman varietas Argomulyo dan Wilis setelah diaplikasi menggunakan cendawan L. lecanii

B. tabaci apabila digunakan sesuai dengan jumlah aplikasi, kerapatan konidia maupun isolat yang digunakan. Cendawan L. lecanii yang digunakan dalam penelitian ini adalah Ll-JTM11, yaitu isolat yang diperoleh dari serangga Leptocorisa acuta (Hemiptera; Alydidae) di Probolinggo pada tahun 2009 yang cukup efektif dalam mengendalikan Riptortus linearis. Hasil penelitian Park \& Kim (2010) menunjukkan efikasi isolat cendawan $L$. lecanii strain 4078 dan Btab01 memiliki virulensi yang sangat tinggi mampu membunuh $B$. tabaci hingga mencapai 99\% bahkan lebih efektif dibandingkan dengan insektisida kimia.
Berat Biji Kedelai Tiap Plot. Hasil berat biji kedelai tiap plot yang berukuran $7 \times 5 \mathrm{~m}$ terbanyak diperoleh dari perlakuan aplikasi cendawan L. lecanii sebanyak sembilan kali dengan kerapatan konidia $10^{9} / \mathrm{ml}$ pada varietas Wilis, yaitu mencapai $6615 \mathrm{~g}$ (Gambar 7). Namun sebenarnya berat biji pada perlakuan tersebut juga tidak berbeda nyata dengan perlakuan aplikasi hanya lima kali menggunakan kerapatan konidia yang sama atau kerapatan konidia yang lebih rendah $\left(10^{7} / \mathrm{ml}\right)$ dengan aplikasi sembilan kali yaitu masing-masing 6300 g dan 6326 g. Perlakuan aplikasi L. lecanii sembilan kali dengan kerapatan konidia $10^{9} / \mathrm{ml}$ pada varietas Wilis 
mampu menekan kerusakan tanaman akibat B. tabaci, karena memperoleh berat kering kedelai tertinggi mencapai $6615 \mathrm{~g}$. Aplikasi 10 kali cendawan L. lecanii dengan kerapatan konidia $10 \% \mathrm{ml}$ lebih efektif dibandingkan dengan aplikasi insektisida lamda sihalotrin karena berat biji yang diperoleh pada perlakuan insektisida kimia hanya $6326 \mathrm{~g}$ meskipun keduanya tidak berbeda nyata.

Pengendalian $B$. tabaci menggunakan cendawan L. lecanii pada varietas Argomulyo belum mampu menekan kehilangan hasil karena berat biji kedelai yang diperoleh lebih rendah dan tidak sebanding dengan efikasi insektisida lamda sihalotrin. Varietas Argomulyo yang terserang $B$. tabaci dan tidak dilakukan pengendalian maka akan kehilangan hasil semakin besar jika dibandingkan varietas Wilis. Varietas Wilis tanpa pengendalian masih memberikan hasil cukup baik karena setara dengan penggunaan varietas Argomulyo yang dikendalikan, baik menggunakan insektisida kimia maupun aplikasi cendawan L. lecanii. Oleh karena itu, untuk menekan populasi $B$. tabaci agar kehilangan hasil di lapangan tidak terjadi maka dianjurkan untuk menanam varietas Wilis.

\section{Pengaruh Aplikasi Cendawan L. lecanii terhadap} Perkembangan Populasi Hama lain. Populasi hama yang ada selain $B$. tabaci juga diamati dengan cara menjaring menggunakan sweeping net sebanyak tiga kali ayunan pada plot yang berukuran 7 x 5 m. Hasil pengamatan menunjukkan bahwa hama lain yang ada adalah hama daun yakni; Empoasca sp., Thrips dan Spodoptera litura (Tabel 3). Dari ketiga jenis hama tersebut, Empoasca sp. menunjukkan populasi yang lebih banyak dibandingkan Thrips maupun S. litura. Populasi Empoasca sp. mulai ditemukan pada tanaman kedelai baik Argomulyo maupun Wilis pada umur 28 HST. Perkembangan populasi mulai meningkat pada umur 42 HST hingga 56 HST, namun populasi turun hingga di bawah 10 ekor pada umur 72 HST. Populasi Empoasca sp. cenderung lebih tinggi pada varietas Wilis dibandingkan Argomulyo. Rendahnya populasi hama ini pada umur 72 HST disebabkan daun tanaman sudah mulai menguning dan sudah tidak menarik lagi Empoasca sebagai tempat berlindung maupun sebagai sumber makanan. Frekuensi aplikasi cendawan $L$. lecanii sembilan kali mengindikasikan populasi Empoasca sp. lebih rendah dibandingkan dengan aplikasi hanya lima kali, baik yang menggunakan kerapatan konidia $10^{7}$ maupun $10 \% / \mathrm{ml}$. Kenyataan tersebut mengisyaratkan bahwa aplikasi cendawan dalam jumlah lebih banyak menyebabkan pengendalian menjadi lebih efektif.

Populasi Thrips sp. lebih rendah dibandingkan Empoasca sp., bahkan populasi Thrips sp. hanya di bawah 20 ekor tiap plot pengamatan. Populasi Thrips sp. mencapai optimal pada umur 42 HST dan pada umur 56 mulai turun hingga populasinya tidak ditemukan pada umur 72 HST. Sedangkan populasi $S$. litura dinilai sangat rendah, yaitu hanya ditemukan pada perlakuan kontrol pada umur 28 sampai dengan 42 HST. Rendahnya populasi $S$. litura disebabkan bukan dari pengaruh aplikasi cendawan $L$. lecanii, namun karena secara alami perkembangan populasi $S$. litura juga rendah di sekitar lokasi penelitian.

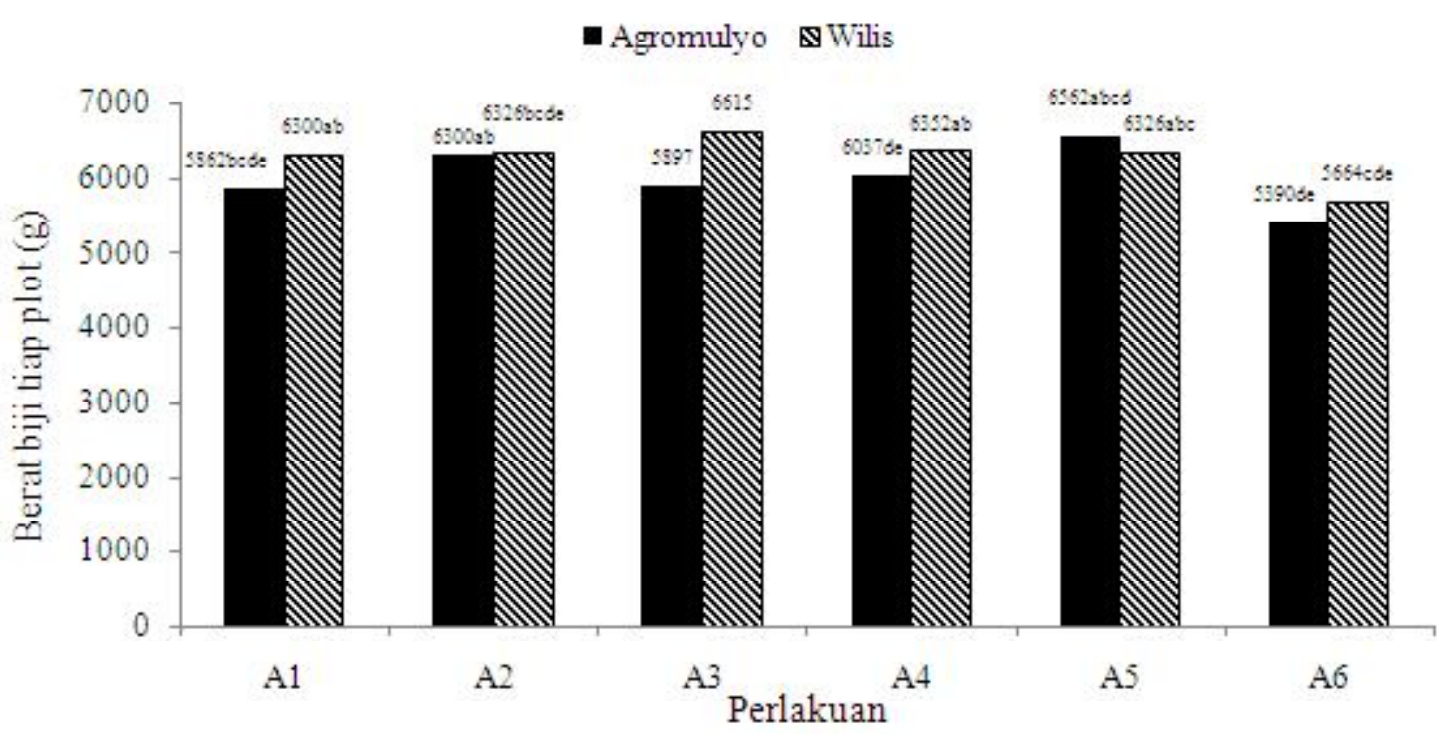

Gambar 7. Berat kering biji tiap plot varietas Argomulyo dan Wilis setelah diaplikasi dengan L. lecanii. 
Tabel 3. Populasi hama Empoasca sp., Thrips sp. dan S. litura sp. setelah aplikasi cendawan L. lecanii

\begin{tabular}{|c|c|c|c|c|c|c|c|c|c|c|c|c|}
\hline \multirow{3}{*}{ Perlakuan } & \multicolumn{12}{|c|}{ Populasi hama pada hari ke... n (HST) } \\
\hline & \multicolumn{4}{|c|}{ Empoasca sp. (ekor) } & \multicolumn{4}{|c|}{ Thrips sp. (ekor) } & \multicolumn{4}{|c|}{ S. litura (ekor) } \\
\hline & 28 & 42 & 56 & 72 & 28 & 42 & 56 & 72 & 28 & 42 & 56 & 72 \\
\hline V1 A1 & 11 & 18 & 19 & 7 & 2 & 4 & 0 & 0 & 0 & 0 & 0 & 0 \\
\hline V1 A2 & 11 & 18 & 23 & 3 & 1 & 11 & 5 & 0 & 0 & 0 & 0 & 0 \\
\hline V1 A3 & 5 & 6 & 18 & 2 & 0 & 4 & 0 & 0 & 0 & 0 & 0 & 0 \\
\hline V1 A4 & 11 & 18 & 23 & 5 & 2 & 5 & 6 & 0 & 1 & 0 & 0 & 0 \\
\hline V1 A5 & 5 & 7 & 5 & 7 & 0 & 0 & 0 & 0 & 0 & 0 & 0 & 0 \\
\hline V1 A6 & 24 & 19 & 31 & 9 & 3 & 13 & 6 & 0 & 1 & 1 & 0 & 0 \\
\hline V2 A1 & 13 & 14 & 29 & 7 & 1 & 2 & 2 & 0 & 0 & 0 & 0 & 0 \\
\hline $\mathrm{V} 2 \mathrm{~A} 2$ & 15 & 11 & 33 & 9 & 2 & 3 & 8 & 0 & 0 & 0 & 0 & 0 \\
\hline $\mathrm{V} 2 \mathrm{~A} 3$ & 14 & 8 & 24 & 10 & 0 & 5 & 4 & 0 & 0 & 0 & 0 & 0 \\
\hline $\mathrm{V} 2 \mathrm{~A} 4$ & 15 & 17 & 37 & 16 & 4 & 6 & 8 & 0 & 0 & 0 & 0 & 0 \\
\hline V2 A5 & 7 & 8 & 11 & 3 & 2 & 0 & 0 & 0 & 0 & 0 & 0 & 0 \\
\hline V2 A6 & 16 & 24 & 59 & 18 & 6 & 7 & 10 & 0 & 1 & 2 & 0 & 0 \\
\hline
\end{tabular}

Keterangan: V1 = varietas Agromulyo; V2 = varietas Wilis

Pengaruh Aplikasi Cendawan L. lecanii terhadap Kelangsungan Hidup Predator. Aplikasi cendawan L. lecanii pada pertanaman kedelai untuk pengendalian B. tabaci ternyata tidak berdampak negatif terhadap kelangsungan hidup serangga berguna, khususnya predator generalis sebagai penghuni permukaan tanah maupun penghuni tajuk. Beberapa jenis predator yang masih mampu hidup pada plot-plot yang diaplikasi menggunakan cendawan $L$. lecanii antara lain: Coccinella sp., Oxyopes sp., dan Paederus sp. (Tabel 4). Populasi predator, khususnya Coccinella dan Oxyopes tampak berlimpah pada tanaman yang berumur 28-56 HST. Diduga kelimpahan predator tersebut berkaitan dengan keberadaan serangga hama yang dimangsa. Selain itu, kondisi tersebut juga dipengaruhi oleh perilaku dan ruang hidup serangga. Predator Oxyopes sp. mempunyai kemampuan yang tinggi dalam memangsa hama sasaran, bahkan setiap ekor Oxyopes sp. mampu mempredasi serangga mangsa mencapa 12 ekor per hari (Tengkano \& Bedjo, 2002). Faktor lain yang mempengaruhi populasi predator diduga struktur integumen predator memiliki lapisan lilin yang lebih tebal dan lebih kuat sehingga suspensi konidia yang disemprotkan dan menempel tubuh predator tidak berhasil menginfeksi karena konidia mati.

Kelimpahan predator Paederus sp. tidak dipengaruhi oleh umur tanaman kedelai, hal ini tampak dari populasi predator tersebut pada umur 72 HST masih cukup banyak dibandingkan umur 56 HST. Selain itu populasi predator juga tidak dipengaruhi oleh varietas kedelai yang ditanam, baik pada Argomulyo maupun Wilis memiliki kelimpahan populasi yang berimbang. Predator Paederus sp., selain menghuni tajuk kedelai juga menghuni permukaan tanah sehingga peluang preferensi mangsa cukup banyak jika dibandingkan dengan predator yang hanya menghuni tajuk kedelai saja. Dengan kata lain, apabila di tajuk tanaman tidak ditemukan mangsa sebagai pakannya maka predator tersebut akan segera pindah ke permukaan tanah untuk mencari mangsa guna memenuhi kelangsungan hidupnya.

Dari hasil penelitian ini mengindikasikan bahwa aplikasi cendawan entomopatogen $L$. lecanii tidak berdampak negatif terhadap kelangsungan hidup predator yang menghuni tajuk maupun penghuni permukaan tanah. Fenomena ini dapat dibandingkan dengan aplikasi insektisida kimia yang cenderung tidak ditemukan adanya musuh alami yang hidup, baik pada kedelai Argomulyo maupun Wilis. Diketahui bahwa ketiga jenis predator tersebut sangat berperan dalam menekan perkembangan populasi hama utama kedelai secara alami, hal ini ditunjukkan dari kapasitas mangsa dari predator tersebut cukup tinggi yaitu mampu memangsa 3-12 ekor hama utama kedelai tiap hari (Tengkano \& Bedjo, 2002). Oleh karena itu, cendawan L. lecanii mempunyai prospek yang baik dapat digunakan sebagai salah satu agens hayati dalam program pengendalian hama terpadu (PHT) untuk mengendalikan B. tabaci. Hal ini disebabkan cendawan L. lecanii dapat dikombinasikan dengan cara 
Tabel 4. Populasi predator pada tiap rumpun kedelai setelah diaplikasi cendawan L. lecanii

\begin{tabular}{|c|c|c|c|c|c|c|c|c|c|c|c|c|}
\hline \multirow{3}{*}{ Perlakuan } & \multicolumn{12}{|c|}{ Populasi predator pada hari ke.....n (HST) } \\
\hline & \multicolumn{4}{|c|}{ Coccinella sp. (ekor) } & \multicolumn{4}{|c|}{ Oxyopes sp. (ekor) } & \multicolumn{4}{|c|}{ Paederus sp. (ekor) } \\
\hline & 28 & 42 & 56 & 72 & 28 & 42 & 56 & 72 & 28 & 42 & 56 & 72 \\
\hline V1 A1 & 0 & 0 & 1 & 1 & 1 & 1 & 0 & 0 & 3 & 0 & 1 & 2 \\
\hline V1 A2 & 5 & 0 & 0 & 0 & 2 & 1 & 2 & 1 & 2 & 0 & 0 & 0 \\
\hline V1 A3 & 1 & 2 & 4 & 0 & 0 & 1 & 1 & 0 & 2 & 1 & 2 & 4 \\
\hline V1 A4 & 2 & 0 & 5 & 0 & 0 & 0 & 0 & 2 & 1 & 0 & 0 & 1 \\
\hline V1 A5 & 0 & 0 & 1 & 0 & 3 & 0 & 0 & 0 & 1 & 0 & 0 & 0 \\
\hline V1 A6 & 1 & 0 & 8 & 1 & 1 & 0 & 0 & 0 & 2 & 4 & 4 & 2 \\
\hline V2 A1 & 3 & 0 & 1 & 1 & 3 & 0 & 0 & 0 & 3 & 2 & 1 & 1 \\
\hline V2 A2 & 7 & 0 & 0 & 1 & 2 & 2 & 1 & 1 & 1 & 1 & 2 & 2 \\
\hline $\mathrm{V} 2 \mathrm{~A} 3$ & 7 & 0 & 4 & 0 & 2 & 0 & 0 & 0 & 0 & 1 & 0 & 0 \\
\hline V2 A4 & 0 & 0 & 3 & 0 & 1 & 3 & 0 & 2 & 1 & 0 & 2 & 2 \\
\hline V2 A5 & 1 & 0 & 3 & 0 & 0 & 0 & 0 & 0 & 1 & 0 & 0 & 0 \\
\hline V2 A6 & 2 & 0 & 2 & 1 & 3 & 2 & 0 & 0 & 0 & 2 & 3 & 3 \\
\hline
\end{tabular}

Keterangan: V1 = varietas Agromulyo; V2 = varietas Wilis

pengendalian lain khususnya predator maupun parasitoid (Goettel et al., 2001; Koike et al., 2005; Kim et al., 2005). Selain itu cendawan tersebut dari hasil penelitian ini juga dapat berfungsi sebagai alternatif pengganti dari insektisida kimia karena cendawan tersebut efikasinya sebanding dengan efikasi insektisida kimia (lamda sihalotrin).

\section{SIMPULAN}

Hasil penelitian ini dapat disimpulkan bahwa varietas Argomulyo (berbiji besar) lebih rentan terhadap serangan B. tabaci dibandingkan varietas Wilis (berbiji kecil). Varietas Wilis yang terserang $B$. tabaci tanpa pengendalian masih mampu menghasilkan produksi sebanding dengan varietas Argomulyo yang dikendalikan menggunakan cendawan $L$. lecanii maupun insektisida kimia. Aplikasi cendawan L. lecanii sebanyak sembilan kali dengan interval tiap minggu mulai umur 14-70 HST dengan kerapatan konidia $10 \% / \mathrm{ml}$ lebih efektif dibandingkan aplikasi lima kali dalam menekan perkembangan populasi $B$. tabaci dan mempertahankan kehilangan hasil setara dengan efikasi insektisida kimia. Aplikasi cendawan L. lecanii lebih aman terhadap kelangsungan hidup berbagai jenis predator dibandingkan dengan aplikasi insektisida kimia. Cendawan entomopatogen $L$. lecanii berpeluang besar dapat digunakan sebagai salah satu agens hayati efektif dan sebagai alternatif pengganti insektisida kimia untuk pengendalian $B$. tabaci.

\section{DAFTAR PUSTAKA}

Arioglu HH, Ozgur AF, \& Isler N. 1989a. Influence of soybean pubescence type and density on whitefly (Bemisia tabaci Genn). resistance. World Soybean Research Conference IV Proceedings III. 1235-1240. Argentina.

Arioglu HH, Ozgur AF, \& Isler N. 1989b. The effect of whitefly (Bemisia tabaci Genn.) damage on yield and yield components in double-cropped soybean production. Soybean Genet. Newslett. 16: 5761.

Botha J, Poole M, \& Hardie D. 2007. Silverleaf whitefly Bemisia tabaci (Biotype B) with reference to related whiteflies in Western Australia. Farmnote 35/2004. Department of Agriculture and Food. www.agric.wa.gov.au[6 September 2011].

Butter NS, Vir BK, Kaur G, Singh TH, \& Raheja RK. 1990. Biochemical basis on resistance to whitefly Bemisia tabaci Genn. (Homoptera: Aleyrodidae) in cotton. Trop. Agric. 69: 119-122.

Byrne DN \& Miller WB. 1990. Carbohydrate and amino acid composition of phloem sap and honeydew produced by Bemisia tabaci. J. Insect Physiol. 36(6): 433-439.

Byrne FJ, Castle S, Prabhaker N, \& Toascano NC. 2003. Biochemical study of resistance to imidacloprid in B biotype Bemisia tabaci from Guatemala. Pest Manag. Sci 59(3): 347-352. 
Charnley AK. 2003a. Fungal pathogens of insects from mechanisms of pathogenicity to host defense. Department of Biology \& Biochemistry University of Bath. http://www.bath.ac.uk/expertice/ showperson.php?employeenumber $=573$ [2 September 2011].

Charnley AK. 2003b. Fungal pathogens of insects: Cuticle degrading enzymes and toxins. Adv. Bot. Res. 40: 241-321.

Davidson EW, Segura BJ, Steele T, \& Hendrix DL. 1994. Microorgaisms influence the composition of honeydew produced by the silverleaf whitefly Bemisia argentifolii. J. Insect Physiol. 40(12): 1069-1076.

Denholm I, Cahill M, Byrne F, \& Devonshire. 1996. Progress with documenting and combating insecticide resistance in Bemisia. In: Gerling D. Mayer R. (ed.). Bemisia 1995: Taxonomy, Biology, Damage, Control and Management, Intercept, Andover UK (1996). Pp: 577-603.

Gindin G, Barash I, Hariri N, \& Raccah B. 1994. Effect of endotoxic compounds isolated from Verticillium lecanii on the sweetpotato whitefly, Bemisia tabaci. Phytoparasitica 22(3): 189196.

Goettel MS, Hajek AE, Siegel JP, \& Evans HC. 2001. Safety of fungal biocontrol agents. In: Butt, T.M., J.W. Jackson \& N. Magan, (Eds.). Fungi as Biocontrol Agents (Progress, Problems and Potential). pp: 347-376. CABI Publishing.

Gulluoglu L, Arioglu H, \& Kurt C. 2010a. Field evaluation of soybean cultivars for resistance to whitefly (Bemisia tabaci Genn). Infestations. Afr. J. Agric. Res. 5(7): 555-560.

Gulluoglu L, Kurt C, Arioglu H, Zaimoglu B, \& Aslan V. 2010b. The researches on soybean (Glycine max Merr.) variety breeding for resistance to whitefly in Turkey. Turk. J. Field Crops. 15(2): 123-127.

Henneberry TJ, Jech LF, \& da la Torre T. 2002. Effets of cotton plant water stress on Bemisia tabaci strain B (Homoptera: Aleyrodidae) honeydew production. Southwest. Entomol. 27(2):117-133.

Hendrix DL, Wel Y, \& Leggett JE. 1992. Homopteran honeydew sugar composition is determined by both insect and plant species. Comp Biochem Physiol 101B: 23-27.
Hilje L \& Morales FJ. 2008. Whitefly bioecology and management in Latin America. In: Capinera, J (ed). Encyclopedia of entomology. pp.42504260. Springer.

Horowitz AR \& Ishaya I. 1996. Chemical control of Bemisia tabaci, management and application. In: Geerling D. \& Meyer RT. (Eds.). Bemisia 1995: Taxonomy, Biology, Damage, Control and management. pp.537-556. Intercept, Andover, Hants, UK.

Isaacs R, Byrne DN, \& Hendrix DL. 1998. Feeding rates and carbohydrate metabolism by Bemisia tabaci (Homoptera: Aleyrodidae) on different quality phloem saps. Physiol. Entomol. 23(3): 241-248.

Islam MdT \& Shunxiang R. 2009. Effect of sweetpotato whitefly Bemisia tabaci (Homoptera: Aleyrodidae) infestation on eggplant (Solanum melongena L.) leaf. J. Pest Sci. 82(3): 211-215.

Junior ALB, Campos ZR, Lourencao AL, \& Campos AR. 2007. Adult attractiveness and oviposition preference of Bemisia tabaci (Genn.) (Homoptera: Aleyrodidae) B-biotype in cotton genotypes. Sci. Agric. 64(2): 147-151.

Kim JJ, Kim KC, \& Roberts DW. 2005. Impact of the entomopathogenic fungus Verticillium lecanii on development of on aphid parasitoid, Aphidius colemani. J. Invertebr. Pathol. 88(3): 254-256.

Koike M, Kodama T, Kikuchi A, Okabe M, Kuramoti K, \& Saito Y. 2005. Effects of Verticillium lecanii (Lecanicillium lecanii) against twospoted spider mite Tetranychus urticae and its natural enemy Phytoseiulus persimilis. $38^{\text {th }}$ Annual meeting of the society for Invertebrate Pathology. August 7-11, 2005 Anchorage, Alaska, USA.

Lam WKF \& Pedigo LP. 2001. Effect of trichome density on soybean pod feeding by adult bean beetles (Coleoptera: Chrysomelidae). J Econ. Entomol. 94(6): 1459-1463.

Lambert AL, McPherson RM, \& Herzog GA. 1997. Field evaluations of fourteen soybean genotypes for resistence to whitefly Bemisia tabaci (Homoptera: Aleyrodidae) infestations. J Econ. Entomol. 90(2): 658-662. 
Lourencao AL, Alves AC, Melo AMT, \& Valle GE. 2011. Development of leaf silvering in squash cultivars infested by silverleaf whitefly. Hortic. Bras. 29(1): 112-116.

Mansaray A \& Sundufu AJ. 2009. Oviposition, development and survivorship of the sweetpotato whitefly Bemisia tabaci on soybean, Glycine max and the garden bean, Phaseolus vulgaris. J. Insect Sci. 9: 1.

McAuslane HJ. 1996. The influence of pubescence on ovipositional preference of Bemisia argentifolii (Homoptera: Aleyrodidae) on soybean. Environ Entomol 25: 834-841.

Murakoshi S, Ichinoe M, Suzuki A, Kanaoka M, Isogai A, \& Tamura A. 2005. Presence of toxic substance in fungus bodies of the entomopathogenic fungi Beauveria bassiana and Verticillium lecanii. Appl. Entomol. Zool. 13(2): 97-102.

Musa PD \& Ren SX. 2005. Development and reproduction of Bemisia tabaci (Homoptera: Aleyrodidae) on three bean species. Insect Sci. 12(1): 25-30.

Park H \& Kim K. 2010. Selection of Lecanicillium strains with high virulence against developmental stages of Bemisia tabaci. Mycobiol. 38(3): 210214.

Perez PT, Clanzio SR, \& Palmer RG. 2009. Inheritance of resistance to whitefly Bemisia tabaci (Gennadius) in soybean. In: Proceedings Soybean Research World Conference. August 10-15, 2009, Beijing, China. Poster No.325.

Perring TM. 2001. The Bemisia tabaci species complex. Crop Prot. 20(9): 725.

Prayogo Y. 2009. Kajian cendawan entomopatogen Lecanicillium lecanii (Zimm.) (Viegas) Zare \& Gams sebagai agens hayati untuk mengendalikan telur hama pengisap polong kedelai Riptortus linearis (F.) (Hemiptera: Alydidae). [Disertasi]. Sekolah Pascasarjana, Departemen Proteksi Tanaman, Institut Pertanian Bogor.
Ren SX, Wang ZZ, Qiu BL, \& Xiao Y. 2001. The pest status of Bemisia tabaci in China and nonchemical control strategies. Insect Sci. 8: 279288.

Ren SX, Ali S, Huang Z, \& Wu JH. 2010. Lecanicillium muscarium as microbial insecticide against whitefly and its interaction with other natural enemies. Current Res, Technol and Educ Tropics in Appl Mirobiol and Microbial Biotechnol: 339-348.

Sidhu JS, Mann RS, \& Butter NS. 2009. Deleterious effects of cotton leaf curf virus on longevity and fecundity of whitefly Bemisia tabaci (Gennadius). J. Entomol. 6: 62-66.

Tengkano W \& Bedjo. 2002. Potensi Oxyopes javanus Thorell (Oxyopidae: Araneae) Memangsa Hama Utama Kedelai. Seminar Nasional Perkembangan Terkini Pengendalian Hayati di Bidang Pertanian dan Kesehatan; Bogor. Institut Pertanian Bogor. 5 September 2002.

Ullah F, Baloch AF, \& Badshah H. 2006. Studies on varietal resistance and chemical control of whitefly (Bemisia tabaci Genn.) in cotton. J. Biol. Sci. 6(2): 261-264.

Wang L, Huang J, You M, \& Liu B. 2005. Effects of toxins from two strains of Verticillium lecanii (Hyphomycetes) on bioattributes of a predatory ladybeetle, Delphastus catalinae (Col.: Coccinellidae). J.Appl. Entomol. 129(1): 32-38.

Wang L, Huang J, You M, Guan X, \& Liu B. 2007. Toxicity and feeding deterence of crude toxin extracts of Lecanicillium (Verticillium) lecanii (Hyphomycetes) against sweet potato whitefly, Bemisia tabaci (Homoptera: Aleyrodidae). Pest Manag. Sci. 63(4): 381-387.

Wilson FD, Flint HM, Stapp BR, \& NJ Parks. 1993. Evaluation of cultivars, germplasm lines, and species of Gossypium for Resistance to Biotype "B" of Sweetpotato whitefly (Homoptera: Aleyrodidae). J. Econ. Entomol. 86(6): 18571862. 